\title{
LUKA NIEDOBORU A MEDIA PUBLICZNE - SZANSE I ZAGROŻENIA
}

\author{
Abstract \\ GAP OF SHORTAGE AND PUBLIC MEDIA - OPPORTUNITIES AND THREATS
}

Polish public media companies are facing strategic choices which are promising but difficult to implement. These exceptional opportunities are especially important to the regional media and they refer to both the Polish Television as well as the radio stations. They result from the deepening of the strategic gap created as a consequence of the erosion of the competitive advantages of traditional providers of media content, particularly regional press. In the face of a lasting trend of dropping sales and readership (and consequently advertising revenue) of newspapers and their weak position in the new media, there is now space for development which can, and should be, filled by the public media. The use of this strategic opportunity may accept the obligations of the public media which result from their public mission - with providing high - quality media content and it should be based on the strategy of public media companies "the television and radio interactions".

Key words: strategy, media, new media, media mission

Spółki polskich mediów publicznych stoją wobec obiecujących, ale i trudnych do realizacji, wyborów strategicznych. Wyjątkowe szanse stojące przed nimi, zwłaszcza przed mediami regionalnymi, odnoszą się zarówno do Telewizji Polskiej, jak i do rozgłośni radiowych. Wynikają one z pogłębiania się luki strategicznej powstałej w konsekwencji erozji przewag konkurencyjnych tradycyjnych dostawców treści medialnych, zwłaszcza regionalnej prasy. W obliczu trwałego trendu, jakim jest spadek sprzedaży i czytelnictwa (a w konsekwencji przychodów reklamowych) tytułów prasowych oraz ich słabej pozycji w nowych mediach, pojawiła się przestrzeń do zagospodarowania, którą mogą i powinny wypełnić media publiczne.

Wykorzystanie tej strategicznej szansy może godzić powinności spoczywające na mediach publicznych, wynikające $\mathrm{z}$ ich publicznej misji, z dostarczaniem wyso- 
kiej jakości treści medialnych i powinno polegać na realizacji strategii publicznych spółek medialnych „telewizji i radia interakcji”.

Zagrożenia związane $\mathrm{z}$ wypełnieniem strategicznej luki płyną z turbulentnego środowiska, w którym dotychczasowe stabilne modele biznesu ulegają dezaktualizacji pod presją destrukcyjnych innowacji i oporu kulturowego wewnątrz organizacji medialnych. Wtóruje im presja wynikająca z zawłaszczania przez korporacje nowomedialne wartości tworzonej przez polskie media publiczne.

\section{Zmiany strategicznego otoczenia}

Współczesne podmioty medialne funkcjonują w otoczeniu, które dostarcza możliwości przetrwania i rozwoju, jest inspiracją, ale jest również źródłem zagrożeń. Ze strategicznej perspektywy szczególnie ważne są główne czynniki napędzające zmiany otoczenia - to od nich zależy powodzenie obranych strategii ${ }^{1}$.

Organizacje medialne starają się dostosować do wszechstronnych rozpoznanych i poznanych zarówno wewnętrznych, jak i zewnętrznych zmian wpływających na sposoby produkcji, pakietowania i dystrybucji, zmiany konkurencji, ewolucji tradycyjnych audytoriów i reklamowych klientów i wpływających na zmianę ustalonych wzorców określających rynkowe pozycje. Wobec tych zmian rośnie potrzeba zrozumienia i dostosowania się do nowych warunków, mogą one bowiem prowadzić do utraty wartości i upadku przedsiębiorstw medialnych².

Zważywszy na strategiczne możliwości rozwoju, istotne są te krytyczne czynniki, które determinują zmiany otoczenia ${ }^{3}$. Ich rozpoznanie ułatwia dostosowanie się do nowych warunków, ich ignorowanie prowadzi natomiast do utraty wartości i upadłości przedsiębiorstw medialnych ${ }^{4}$.

Identyfikując podstawowe czynniki wpływające na funkcjonowanie przedsiębiorstw medialnych, można wskazać na globalizację, regulacje prawne, gospodarki krajowe, technologie i aspekty społeczne. Biorąc pod uwagę aktywność użytkowników mediów, którzy współtworzą z organizacjami medialnych ich wartość rynkową, można przyjąć, że czynniki powyższe mają charakter wewnętrzny i zewnętrzny:

1) Globalizacja - obejmuje także nabywanie spółek i lokalizowanie firm medialnych w innych krajach;

2) Regulacje - wpływają na utrzymanie konkurencji, ochronę pracowników, zapewniają także dochody podatkowe;

${ }^{1}$ G. Johnson, K. Scholes, R. Whittington, Podstawy strategii, PWE, Warszawa 2010, s. 50.

2 R.G. Picard, Environmental and Market Changes Driving Strategic Planning in Media Firms [w:] Strategic Responses to Media Market Changes, red. R.G. Picard, JIBS Research Reports. Jonkoping International Business School 2004, s. 2.

${ }^{3}$ G. Johnson, K. Scholes, R. Whittington, Podstawy..., s. 50.

${ }^{4}$ R.G. Picard, Environmental..., s. 2. 
3) Gospodarki krajowe - wpływają na grę sił rynkowych identyfikowaną przez analizę koncepcji makro- i mikroekonomicznych;

4) Rozwój technologii - wspiera i zaburza rozwój mediów. Innowacje przyspieszają wzrost, umożliwiając dystrybucję i odbiór mediów. Nadmierny postęp technologiczny zmusza firmy medialne do nadążania za nim, gdy nieznane pozostają wybory odbiorców co do nowo wprowadzanych technologii. Cyfrowe środowisko zmienia tradycyjne modele biznesowe ${ }^{5}$;

5) Społeczne aspekty - audytorium nie jest już traktowane jako masa, ale agregat wielu zróżnicowanych demograficzne i etnicznie grup o odmiennych stylach życia i różnych potrzebach. Uwzględniając wszystkie możliwości dostępu do rozrywki i informacji w cyfrowej postaci, nadal duża pozostaje fragmentacja, publiczność jednak nie tylko konsumuje medialne treści, ale i tworzy je na liczne sposoby ${ }^{6}$.

$\mathrm{W}$ takich warunkach strategiczne wybory podejmowane przez menedżerów mediów dyktowane są, jak przekonuje Robert Picard, przez następujące rodzaje sił:

1) Rynkowe. Zewnętrzne, oparte na strukturach i wyborach rynkowych. Sukces i wzrostu zależy od zysków i przychodów niezbędnych do skutecznego konkurowania. Dotyczą kapitału, popytu na produkty i usługi medialne oraz konkurencji.

Możliwość pozyskiwania kapitału ogranicza liczbę firm działających na rynku zwłaszcza na rynkach krajów rozwijających się o mniej stabilnych walutach i mniej rozwiniętych rynkach finansowych. Z kolei konsumpcja mediów wymaga rzadkich zasobów (czas i pieniądze). Popyt ze strony reklamodawców zależy natomiast przede wszystkim od potrzeb uzyskania dostępu do audytoriów i danych udostępnianych na ich temat. Większość reklam jest częścią szeroko zakrojonych wysiłków marketingowych mających na celu skupienie uwagi odbiorców na ich produktach, wzrost sprzedaży tych produktów i pozyskanie lojalnych nabywców.

2) Różne dla poszczególnych medialnych platform koszty stałe i zmienne. Znaczące różnice dotyczą kosztów produkcji medialnego kontentu. W przypadku na przykład telewizji i radia to od $1 / 4$ do $1 / 3$ kosztów całkowitych, $\mathrm{w}$ internecie natomiast koszty dystrybucji są zwykle ponoszone przez użytkowników.

3) Regulacje. Choć media cieszą się znaczącą w warunkach demokracji swobodą ekspresji, rządy regularnie interweniują na medialnych rynkach, deklarując przynajmniej między innymi potrzebę równowagi różnych poglądów i punktów widzenia.

${ }^{5}$ J. Kreft, Ewolucja strategii transmedialnych korporacji transnarodowych, Wydawnictwo Uniwersytetu Gdańskiego, Gdańsk 2012.

${ }^{6}$ A. Albarran, The Media and Communication Industries: A 21st Century Perspective - External Forces Transforming the Media Industries, Revista Com Humanitas. 
4) Bariery wejścia i mobilności. To czynniki utrudniające skuteczne konkurowanie na rynku, ograniczające pole strategicznych decyzji. Dotyczą one przede wszystkim kosztów, działań regulacyjnych i charakteru rynku. Ich wpływ ujawnia się w przypadku nowo powstających przedsięwzięć i przy okazji poszerzania działalności o nowe rynki. Tradycyjnie barierą wejścia są wymagania kapitałowe oraz tak zwana ekonomia skali, barierą jest także ograniczony dostęp do kanałów dystrybucyjnych ${ }^{7}$.

Do najważniejszych z wymienionych czynników należą te, które mają charakter destrukcyjnych innowacji. Dzieląc innowacje na podtrzymujące dotychczasowe stosunki oraz przełomowe, te pierwsze Chris Christensen określa jako przyczyniające się do wzrostu jakości i produktywności dotychczasowych rozwiązań. Drugie to technologie nowe, które dostarczają niedostępnych wcześniej wartości ${ }^{8}$. Przyczyniają się one do kształtowania niestabilnego otoczenia charakteryzowanego zazwyczaj dodatkowo poprzez konwergencję przemysłów telekomunikacyjnego, komputerowego i medialnego oraz tak istotne zmiany związane $\mathrm{z}$ rozwojem mediów społecznościowych, że to $\mathrm{z}$ ich perspektywy opisywana jest ewolucja internetu. W takim otoczeniu szybko dezaktualizują się tradycyjne modele biznesu, ale i powstają nowe rynkowe okazje. Niepewności co do przyszłej dominującej technologii towarzyszą unikatowe okazje rynkowe.

\section{Luka strategiczna}

Luka strategiczna powstaje $\mathrm{w}$ wyniku odchylenia pożądanego i przewidywanego rozwoju przedsiębiorstw ${ }^{9}$. Luka ta występuje pomiędzy naturalnymi możliwościami wzrostu przedsiębiorstw a osiąganymi przez te przedsiębiorstwa wyni$\mathrm{kami}^{10}$. Groźba powiększania tych rozbieżności powinna skłaniać przedsiębiorstwa medialne do korekty bądź radykalnej zmiany strategii przez kompleksową restrukturyzację.

Dzięki analizie luki strategicznej można dostosować dotychczasową strategię do zmian otoczenia, tych przeszłych i prognozowanych. Pozwala ona na wyeliminowanie różnic pomiędzy celami strategicznymi organizacji a potrzebami interesariuszy, zwłaszcza zewnętrznych. Gdy są one rozbieżne, niezbędna jest zmiana stra-

7 R.G. Picard, The Economics and Financing of Media Companies, Fordham University Press, New York 2002.

${ }^{8}$ C.M. Christensen, The Innovator's Dilemma: When New Technologies Cause Great Firms to Fail, Harvard Business School Press, Boston 1997; J. Bower, C.M. Christensen, Customer power, strategic investment, and the failure of leading firms, „Strategic Management Journal” 1996, vol. 17, s. 197-218.

${ }^{9}$ H.J. Vollmuth, Controlling. Instrumenty od A do Z, Wydawnictwo Placet, Warszawa 1995, s. 294.

${ }^{10}$ C. Suszyński, Restrukturyzacja przedsiębiorstw. Proces zarządzania zmianami, PWE, Warszawa 1999, s. 84. 
tegii. Gdy rozpiętość ta jest bardzo duża, konieczna jest także dalsza analiza potrzeb rozwojowych.

Analiza rozpiętości pozwala na identyfikację trzech rodzajów luk strategicznych ${ }^{11}$ :

1) Luka zgodności, czyli zgodność kierunków obu trendów w przedsiębiorstwie i otoczeniu - firma utrzymuje wtedy swój udział w sektorze mediów;

2) Luka nadmiaru, kiedy analizowana organizacja rozwija się szybciej niż tempo wzrostu sprzedaży wszystkich producentów lub usługodawców w sektorze mediów;

3) Luka nied obor u, kiedy w analizowanym przedsiębiorstwie wzrost sprzedaży jest znacznie wolniejszy niż dynamika sprzedaży całego sektora, co powoduje zmniejszenie udziału firmy w rynku.

Należy dodać, że analiza luki strategicznej może być dokonana na poziomie strategicznym i operacyjnym. Im luka strategiczna jest większa, tym większy jest jej wpływ na zmiany organizacji i wielkość innej luki - budżetowej oraz luki operacyjnej.

\section{Luka niedoboru w mediach regionalnych}

Przedstawione wyżej podstawowe wyzwania strategiczne oraz pogłębiająca się słabość regionalnych wydawców prasy, a ponadto praktyki zawłaszczania korzyści przez organizacje nowych mediów pozwalają na sformułowanie następujących hipotez:

- Przedsiębiorstwa starych mediów, zwłaszcza wydawnictwa prasowe, kultywując tradycyjne rozwiązania (modele biznesowe), pogłębiają lukę strategiczną.

- Powstała luka strategiczna otwiera nowe możliwości (strategiczne okazje) dla mediów publicznych, zwłaszcza regionalnych rozgłośni radiowych i oddziałów telewizji publicznej.

Na polskim rynku dostawców treści medialnych dokonuje się istotne, trwałe przesunięcie pozycji konkurencyjnej oraz erozja przewag konkurencyjnych tradycyjnych dostawców, zwłaszcza prasy. Trwały charakter ma trend spadkowy sprzedaży i czytelnictwa (a w konsekwencji przychodów reklamowych) dominujących tytułów prasowych, zarówno informacyjnej prasy ogólnopolskiej, jak i prasy regionalnej (tab. 1-3).

${ }^{11}$ G. Gierszewska, M. Romanowska, Analiza strategiczna przedsiębiorstwa, PWE, Warszawa 2002, s. 51. 
Tabela 1. Gazety ogólnopolskie. Zmiana sprzedaży (2004-2014, II kw.)

\begin{tabular}{|l|c|}
\hline \multicolumn{1}{|c|}{ Tytuł } & Sprzedaż wydań papierowych \\
\hline „Puls Biznesu” & $-78 \%$ \\
\hline „Rzeczpospolita” & $-73 \%$ \\
\hline „Gazeta Wyborcza” & $-61 \%$ \\
\hline „Fakt” & $-35 \%$ \\
\hline „Super Express” & $-34 \%$ \\
\hline
\end{tabular}

Źródło: obliczenia własne, ZKiDP 2004, II kw. 2014.

Tabela 2. Gazety ogólnopolskie, czytelnictwo (2004-2014, II kw.)

\begin{tabular}{|l|c|c|}
\hline \multicolumn{1}{|c|}{ Tytuł } & Czytelnictwo w 2004 r. & Czytelnictwo w 2014 r. \\
\hline „Fakt” & 23 & 11 \\
\hline „Gazeta Wyborcza” & 19 & 11 \\
\hline „Super Express” & 11 & 5 \\
\hline „Rzeczpospolita” & 4 & 3 \\
\hline
\end{tabular}

Źródło: obliczenia własne, ZKiDP 2004, II kw. 2014.

Tabela 3. Prasa regionalna. Zmiana sprzedaży (2004-2014, II kw.)

\begin{tabular}{|l|c|}
\hline \multicolumn{1}{|c|}{ Tytuł } & Spadek sprzedaży \\
\hline „Dziennik Polski” & $-61 \%$ \\
\hline „Gazeta Pomorska” & $-48 \%$ \\
\hline „Gazeta Lubuska” & $-48 \%$ \\
\hline „Dziennik Łódzki” & $-47 \%$ \\
\hline „Express Ilustrowany” & $-42 \%$ \\
\hline „Dziennik Zachodni” & $-36 \%$ \\
\hline „Echo Dnia” & $-33 \%$ \\
\hline „Głos Wielkopolski” & $-23 \%$ \\
\hline
\end{tabular}

Źródło: obliczenia własne, ZKiDP 2004, II kw. 2014. 
Tabela 4. Najpopularniejsze witryny internetowe w Polsce (informacje i publicystyka)

\begin{tabular}{|l|c|c|}
\hline \multicolumn{1}{|c|}{ Witryna } & Użytkownicy (w mln) & $\begin{array}{c}\text { Odsłony krajowe ogółem } \\
(\mathbf{w} \text { mln })\end{array}$ \\
\hline Grupa Onet & 8,4 & 394 \\
\hline Grupa Polskapresse - Media Regionalne & 7,3 & 173 \\
\hline Grupa Wirtualna Polska & 7,1 & 265 \\
\hline Grupa Gazeta.pl & 6,1 & 203 \\
\hline Grupa Interia.pl & 4,1 & 101 \\
\hline Grupa TVN & 3,4 & 110 \\
\hline Grupa Murator - Time & 2,3 & 18 \\
\hline Grupa Cyfrowy Polsat & 1,5 & 21 \\
\hline Grupa TVP & 1,4 & 11 \\
\hline Grupa Polskie Radio & 1,2 & 8 \\
\hline
\end{tabular}

Źródło: Megapanel PBI/Gemius.

Tabela 5. Najpopularniejsze witryny internetowe w Polsce (biznes, finanse i prawo)

\begin{tabular}{|l|c|c|}
\hline \multicolumn{1}{|c|}{ Witryna } & Użytkownicy (w mln) & $\begin{array}{c}\text { Odsłony krajowe ogółem } \\
\text { (w mln) }\end{array}$ \\
\hline Grupa Onet & 8,4 & 394 \\
\hline Grupa Polskapresse - Media Regionalne & 7,3 & 173 \\
\hline Grupa Wirtualna Polska & 7,1 & 265 \\
\hline Grupa Money.pl & 3,7 & 35 \\
\hline Grupa Infor & 3,5 & 27 \\
\hline Grupa Bankier.pl & 2,4 & 39 \\
\hline Grupa Gazeta.pl & 2,3 & 22 \\
\hline Grupa Interia.pl & 4,1 & 101 \\
\hline egospodarka.pl & 1,4 & 7 \\
\hline Grupa Gofin.pl & 1,2 & 15 \\
\hline Grupa Gremi Business Communication & 1,0 & 10 \\
\hline
\end{tabular}

Źródło: Megapanel PBI/Gemius, średnia II kw. 2014. 
Tabela 6. Sprzedaż e-wydań gazet ogólnopolskich (II kw. 2014)

\begin{tabular}{|l|c|}
\hline \multicolumn{1}{|c|}{ Tytuł } & Liczba abonentów \\
\hline „Puls Biznesu” & 2400 \\
\hline „Rzeczpospolita” & 8300 \\
\hline „Gazeta Wyborcza” & 2000 \\
\hline „Dziennik Gazeta Prawna” & 9400 \\
\hline „Fakt” & 230 \\
\hline „Super Express” & 24 \\
\hline
\end{tabular}

Źródło: ZKiDP 2004, II kw. 2014.

Powyższe zestawienie potwierdzają znaczące pogorszenie pozycji konkurencyjnej wydawnictw prasy informacyjnej jako dostawców treści medialnych. Szczególnie dotkliwe spadki dotyczą mediów regionalnych.

Spadkom sprzedaży i czytelnictwa prasy towarzyszy brak zainteresowania użytkowników ofertą wydań on-line oraz, ogólnie, słabnący potencjał konkurencyjny wydawców prasy informacyjnej (tab. 6).

Notowane spadki w niewielkim stopniu rekompensowane są przez aktywność wydawców na wysoko konkurencyjnym rynku portali informacyjnych (tab. 4, 5) przez Onet i Wirtualną Polskę (zwłaszcza w odsłonach krajowych ogółem).

Erozji ulega tradycyjny model funkcjonowania mediów regionalnych zdominowanych przez lata przez tytuły prasowe. Wydawnictwa prasowe były najważniejszymi dostarczycielami treści informacyjnej. Pozostającej po nich przestrzeni rynkowej nie wypełniają, poza nielicznymi wyjątkami (Trójmiasto.pl), regionalne portale informacyjne.

\section{Wypełnianie luki przez media publiczne - szanse i zagrożenia}

Z perspektywy podmiotów mediów publicznych, których konkurencyjna pozycja jest wzmacniana przez przychody abonamentowe, pojawiła się zatem (i powiększa) strategiczna luka niedoboru, którą media te mogą wypełnić.

Media publiczne, wśród których nie ma tytułów prasowych, nie miały w ostatnich 25 latach równie obiecujących (ale i trudnych do realizacji) wyborów strategicznych. Dotyczy to zarówno Telewizji Polskiej, jak i rozgłośni radiowych.

Luka powyższa dotyczy zarówno treści medialnych oferowanych przez stacje telewizyjne i rozgłośnie radiowe off-line i on-line. Jej wypełnienie powinno:

- godzić powinności spoczywające na mediach publicznych wynikające z wypełniania przez nie publicznej misji oraz dostarczania wysokiej jakości treści medialnych; 
- polegać na realizacji strategii publicznych spółek medialnych „telewizji i radia interakcji”.

Strategia uwzględniająca wypełnienie luki niedoboru powinna zatem uwzględniać podstawowe pryncypia związane z pełnioną misją publiczną:

- dostarczanie informacji;

- udostępnianie dóbr kultury:

- ułatwianie korzystania z oświaty i dorobku nauki,

- dostarczanie rozrywki,

- popieranie krajowej twórczości audiowizualnej.

Pryncypia powyższe pozostają $\mathrm{w}$ zgodzie $\mathrm{z}$ istotnym warunkiem efektywności wypełnienia strategicznej luki, jakim jest pokonanie bariery barier kompetencji starych mediów.

Realizacja strategii wypełniania luki nie jest wolna od zagrożeń. Zaliczyć do nich należy, oprócz kolejnej destrukcyjnej innowacji, np. niestabilność wpływów abonamentowych. $Z$ perspektywy organizacjami starych mediów można także mówić o barierze umiejętności efektywnego zarządzania w nowych mediach.

Ważnym ograniczeniem wewnątrzorganizacyjnym jest także organizacyjna „blokada kulturowa” występująca pod postacią:

- utartych, tradycyjnie praktykowanych schematów rozwiązywania problemów;

- braku zdolności decyzyjnych;

- nieefektywnych lub zbyt rozbudowanych systemów kontrolnych.

Ograniczenia we wdrażaniu korekty dotychczasowych strategii w mediach publicznych mogą wynikać z oporu wewnątrzorganizacyjnego, przejawiającego się niechęcią do zmiany dotychczasowych przyzwyczajeń i standardów.

Opór kulturowy ma także szerszy wymiar. Polega na minimalizacji i lekceważeniu zagrożeń dla długotrwałej dziennikarskiej praktyki, podkreślaniu konieczności utrzymania standardów tradycyjnego dziennikarstwa ${ }^{12}$. Niechęć do wykorzystywania nowych rozwiązań technologicznych, nieufność wobec wartości nieprofesjonalnych treści medialnych oraz interpretacja internetu jako platformy przydatnej przede wszystkim reklamodawcom, składają się na zidentyfikowany i analizowany kulturowy opór przedstawicieli tradycyjnego dziennikarstwa ${ }^{13}$. Oznacza to w praktyce, że - jak sugeruje Leopoldina Fortunati analizująca (z zespołem) europejski rynek medialny - dziennikarstwo multimedialne może być strategicznym celem menedżerów, pozostając poza aspiracjami zawodowymi dziennikarzy ${ }^{14}$. Z jednej strony rozwój internetu jest pozytywnie przyjmowany jako przede wszystkim udo-

12 A. Hermida, The Blogging BBC: Journalism blogs at 'the world's most trusted news organisation, „Journalism Practice” 2009, vol. 3, no. 3, s. 269.

${ }_{13}$ J.B. Singer, Strange bedfellows? The diffusion of convergence in four news organizations, „Journalism Studies" 2004, vol. 5, no. 1, s. 3-18.

${ }^{14}$ L. Fortunati et al., The influence of the Internet on European journalism, „Journal of Computer-Mediated Communication" 2009, vol. 14, no. 4, s. 952-953. 
godnienie przyczyniające się do zwiększenia komunikacyjnej wydajności. Z drugiej jednak strony profesjonalni dziennikarze nie są gotowi do porzucania konwencji tradycyjnego dziennikarstwa ${ }^{15}$.

Oporowi kulturowemu towarzyszy presja organizacji nowych mediów, zwłaszcza takich korporacji, jak Google, Facebook, Twitter czy Pinterest, dysponujących unikatowymi kompetencjami związanymi z zarządzaniem przez organizacje nowomedialną siecią relacji ${ }^{16}$. W praktyce polega ona na:

1) Organizowaniu/stymulowaniu aktywności użytkowników.

2) Zachęcaniu użytkowników do tworzenia wartości użytkowej w sieci relacji między nimi i kluczowymi węzłami (przedsiębiorstwami medialnymi) sieci relacji.

3) Permanentnej rekonfiguracji ich ról i relacji w sieciowej konstelacji użytkowników i organizacji medialnych.

Tymi kompetencjami nie dysponują, bądź dysponują w ograniczonej mierze, spółki starych mediów, które stosunkowo późno zaangażowały się w działania w internecie, traktując je przede wszystkim jako formę promocji, np. tradycyjnych wydań prasy.

\section{Wnioski i sugestie badawcze}

Przedstawiana koncepcja wypełnienia przez media publiczne luki niedoboru wynikającej ze słabości rynkowej dotychczasowych liderów regionalnej prasy ma charakter ogólny, modelowy. Na każdym z regionalnych rynków ma ona odmienne cechy charakterystyczne i odmienny wymiar rynkowy. Różne są także, jeżeli występują, czynniki krytyczne zmiany, tak jak różne są zasięg i zakres na przykład oporu kulturowego wewnątrz organizacji. Kwestie te wymagają odrębnych analiz i pogłębionych badań, począwszy od poznania wpływu ogólnokrajowych mediów na pozycję konkurencyjną mediów regionalnych. Prac badawczych wymaga ponadto wpływ nowomedialnych korporacji na funkcjonowanie mediów tradycyjnych na poszczególnych regionalnych rynkach oraz współpraca z tym korporacjami spółek mediów publicznych (np. powszechna praktyka odsyłania użytkowników na profile stacji telewizyjnych i radiowych na Facebooku).

Oddzielnych, ale uzupełniających, badań wymaga również wpływ malejących przychodów wydawców na spadek profesjonalizmu powstawania treści medialnych, pogorszenie pozycji zawodowych profesjonalnych dziennikarzy regionalnych mediów oraz jakość produktów medialnych.

${ }^{15} \mathrm{~J}$. O'Sullivan, A. Heinonen, Old values, new media: Journalism role perception in a changing world, „Journalism Practice” 2008, vol. 2, no. 3, s. 357-371.

${ }_{16} \mathrm{~J}$. Kreft, Za fasadą społeczności. Zarządzanie nowymi mediami, Wydawnictwo Uniwersytetu Jagiellońskiego, Kraków 2015. 


\section{Bibliografia}

Albarran A., The Media and Communication Industries: A 21st Century Perspective - External Forces Transforming the Media Industries, Revista Com Humanitas.

Bower J., Christensen C.M., Customer power, strategic investment, and the failure of leading firms, „Strategic Management Journal” 1996, vol. 17, s. 197-218.

Christensen C.M., The Innovator's Dilemma: When New Technologies Cause Great Firms to Fail, Harvard Business School Press, Boston 1997.

Fortunati L. et al., The influence of the Internet on European journalism, „Journal of Computer-Mediated Communication" 2009, vol. 14, no. 4, s. 928-963.

Gierszewska G., Romanowska M., Analiza strategiczna przedsiębiorstwa, PWE, Warszawa 2002.

Hermida A., The Blogging BBC: Journalism blogs at 'the world's most trusted news organisation, „Journalism Practice” 2009, vol. 3, no. 3.

Johnson G., Scholes K., Whittington R., Podstawy strategii, PWE, Warszawa 2010.

Kreft J., Ewolucja strategii transmedialnych korporacji transnarodowych, Wydawnictwo Uniwersytetu Gdańskiego, Gdańsk 2012.

Kreft J., Za fasadą społeczności. Zarządzanie nowymi mediami, Wydawnictwo Uniwersytetu Jagiellońskiego, Kraków 2015.

O'Sullivan J., Heinonen A., Old values, new media: Journalism role perception in a changing world, „Journalism Practice” 2008, vol. 2, no. 3, s. 357-371.

Picard R.G., Environmental and Market Changes Driving Strategic Planning in Media Firms [w:] Strategic Responses to Media Market Changes, red. R. Picard, JIBS Research Reports. Jonkoping International Business School 2004.

Picard R.G., The Economics and Financing of Media Companies, Fordham University Press, New York 2002.

Singer J.B., Strange bedfellows? The diffusion of convergence in four news organizations, „Journalism Studies" 2004, vol. 5, no. 1, s. 3-18.

Suszyński C., Restrukturyzacja przedsiębiorstw. Proces zarządzania zmianami, PWE, Warszawa 1999.

Vollmuth H.J., Controlling. Instrumenty od A do Z, Wydawnictwo Placet, Warszawa 1995.

ZKiDP 2004, II kw. 2014. 